\title{
Invalidity Juridical Acts and Its Classification
}

\author{
Entela Abduli \\ entela. abduli@yahoo.com \\ Universiteti Europian I Tiranes
}

\begin{abstract}
Based on the kind of invalidity juridical acts and contracts in Albanian Law are generally classified in absolute and relative invalid acts. The difference between them and the consequences are defined in Albanian Civil Code. Invalidity of juridical as a very important aspect of rights was first mentioned in traditional albanian system of rules and then defined in Civil Code of 1929 of King Zogu "About juridical acts and obligations",Civil Code of National Albanian Republic of 1981 and actual Civil Code of 1994. This work aims to analyze classification of invalid juridical acts and the elements that cause this invalidity. For this purpose are taken into consideration actual juridical literature, laws and their changes, Unified sentences of Supreme Tribunal Court and collected database from different courts. While analyzing this database the question that arises is: whether classification of invalid juridical acts is important in adjusting consequences derived from these acts.
\end{abstract}

Keywords: Nullity, cancelation, solution to consequences, absolute invalidity, relative invalidity.

\section{Introduction}

Juridical acts are considered invalid when law violence is noticed or will of parts is threatened and doesn't correspond to the real will of parts to make an agreement, contract or other juridical act.

Albanian Civil Code classifies invalid juridical acts in two categories:

1. The ones noticed invalid

Juridical acts noticed invalid are considered absolutely invalid

2. The ones declared invalid

Juridical acts declared invalid are the relative ones that bring juridical consequences until the moment are declared invalid from the court.

\section{ABSOLUTELY INVALID JURIDICAL ACTS}

Absolut Invalidity is the hardest form of juridical invalidity because the act is supposes as never done and doesn't bring any consequence. According to actual law juridical act is considered nul when one of the main conditions of creating the act is lacking or is in discordance with ordering disposite of law. Juridical act is null from the moment of its execution, so the court doesn't have to take into consideration consequences this act cause to third parts. Nevertheless in many times absolute invalidity is asked from the parts in court. In these cases the court has to consider the consequences because this is asked from involved parts.

Some of the kinds of absolutely invalid acts are as below: 


\section{Juridical acts created in discordance with the certain form}

One of the base conditions of juridical acts is creation of it in the right form defined in law. If a juridical act isn't written down in letter when this is defined in the ordering part of law this act is considered invalid. In this case the written form is the main condition of the act content. Absolute invalidity of juridical act caused from uncertain form of it defined in law can't be later valid. The only case when invalidity can be surpassed is earning property prescription as a form of earning proprietorship when element time and possession of property is fulfilled. Conclusively juridical acts when written form is missing are considered invalid. This case is common in court practices.

\section{Illegal juridical acts}

Acts are considered illegal when they are in discordance with the ordering or preventing part of the law. These acts are divided in those illegal and those who are made to deceive the law. When acts are in discordance with law is not necessary to be proved that are made with the purpose to break the law because the act was prevented with the ordering part of the law. The act is considered absolutely invalid and for this is not necessary to be proved the acknowledgement of the law from the parts. Their lack of knowledge doesn't justify the absolute invalid act. Nevertheless this doesn't mean that the component good faith isn't taken into consideration. It's importance is necessary to resolve the consequences of invalidity between parts that have been in good faith. There are thoughts that the act can be invalid even when is in discordance with rules and tradition but this kind of invalidity is not specified in law. In this category are also involved juridical acts done to deeive the law. These acts look like legal but hide in themselves elements of abuse. The will expressed in these acts doesn't correspond to the internal will of the person, as one of the basic element of a valid juridical act. This lack of will is illegal that is why the act is considered invalid. The person who does the juridical is aware of its illegality because acts consciously and wants the consequences according to his interest.

\section{Fictive or simulated juridical acts done with agreement of parts not having as purpose to bring juridical consequences}

Fictive juridical acts are the ones done by the parts only for appearance not having purpose to bring juridical consequences, or creating/changing juridical relations. In these acts the purpose and the will of the parts to change a juridical relation is not expressed that is why are considered absolutely invalid. For example when a person wants to hide a property from the bank that has given a loan makes a fictive sell contract, not having as purpose to sell the property. These acts are invalid even when their content is legal. Fictive juridical acts are easily made in the everyday life like donating, selling, borrowing or partnership in business enterprises. Simulated juridical acts are the ones absolutely invalid made to hide another act that the parts don't want to publish. The real act in this case is hidden from the simulated act that doesn't purpose to bring any consequence except from hiding the real purpose of the parts. These acts are considered invalid because they lack of purpose while the hidden act is considered valid as long as is made according to law. When the simulated act hides another act, its validity is checked from the court. When the court realizes that the real juridical act isn't threatened from illegal components this act is taken into consideration. Usually simulated juridical acts are made to deceive the law or to hide an illegal act. As long as fictive and simulated acts are made only for appearance, not aiming to create or change juridical consequences they are considered null.

\section{Sentence number 932 of 22. 06. 2000 of Unified Tribunal of Supreme Court Tirana}

About the case with accusing part Spiro Kristo and accused part Anastas Recka with object: declaring invalid rental contract number 1757 rep $599 \mathrm{kol}$ of 14. 10. 1996. Unified Tribunal of Supreme Court came to conclusion that is time to unify court practice for these cases.

1. When juridical act can be considered simulated and the elements that makes it so?

\section{How can article $686 / 2$ of Civil Code be interpreted about lose or damage of the parts in contract?}

First Level Court of Saranda has canceled the accuse while Second Level Court has changed first sentence and declared invalid rental contract allowing the parts to fulfill contract agreement between them and "Kamberi" company. Civil Tribunal of Supreme Court has changed second sentence approving first sentence. Unified Tribunal of Supreme Court notices that according to this process in first and second level involved parts Spiro Kristo and Anastas Recka have made a rental 
contract for the amount 12.500. 000 (greek currency) within a year. So in the end of the year the borrowing part has to pay back the money including interest percentage, and the loan is guaranteed with a store. In the same date Spiro Kristo has made a contract with "Kamberi" company for the same amount of money but including Anastas Recka as a creditor part. Spiro Kristo has raised the accuse pretending that rental contract between him and Anastas Recka is a simulated act because there is a lack of the real will of the parts and appeared will, realized in the form of written contract at the attorney's office. As the accusing part pretends the real will was depositing the money in the "Kamberi" company (a year later this rental company proved to be bankrupted) with the intermediary part. The purpose was to get the money back after a year including interest percentage that would be equal to the amount described in the simulated rental contract. These pretends are proved to be not based in law and facts while accused part Anastas Recka denied to have had the purpose or will to deposit the money in "Kamberi" company. Also in this cases we dont have the opposite claim which is a special agreement where parts express the will to make a simulated agreement. Also it can be proved that the purpose of the accusing part was to deposit to "Kamberi" company the amount he had rented aiming to reach the time to give back the money he had rented from the accused part. Also the contract signed with "Kamberi" company cannot be considered as in interest of a third person because there is mentioned the accused part name so the third person in this case can only benefit without counter-payment not taking any risk. No contract can make a person creditor or debtor without his will. Unified Tribunal reasons that creditor cannot interfere in the way debtor uses the money, but can only ask the money and the interests back when is time according to the contract. However Unified Tribunal judges as mistaken the fact that first and second level court have considered valid the rental contract because it is in discordance with any economic logic. They reason that any bank or trade activity cannot reach that percentage of profiting so those interests can be paid. Our Civil Code doesn't put any limit to the allowed payments and interests while some other countries law define it. This Code accepts all principles of freedom contracting and competition as a fair procedure in a free trade of goods and capitals but in a threatened and abused trade from illegal invasions we have the opposite of free contracting. As the limit of maximal payments due to rent isn't predicted in articles of special part of Civil Code the court should refer to the general articles of economic aspect of obligation. According to article 442 of Civil Code "creditor and debtor should act correctly and be impartial according to terms of reasoning that means freedom of contracting is not absolutely limitless. According to article 686/2 of actual Civil Code general conditions that bring damages to the contracted parts in a disproportional way are invalid especially when are totally different with terms of equality and equity of contractual relations. In the above case rental contract is legal but according to article 686/2 of Civil Code payable interests go beyond the economic logic. Nevertheless the court should reason that invalid parts don't necessarily make turn invalid the juridical act because according to article 111 of Civil Code "When the reason of invalidity involves only a part of the act this act remains valid in the other parts except for the case all parts are indivisible with the invalid part of juridical act"

Unified tribunals reason that putting as guarantee the property enforces the fact that the purpose of both parts was to make the rental contract because the pretend of accused part to be guaranteed for the payment is an uncontested evidence of the validity of the contract. In the end the Tribunal reasons that the contract should be declared invalid only for the payable interests to be returned at the end of the year.

\section{Acts made from incapable to act people}

According to the law one of the conditions that the act can be valid is the juridical capability to act of the person, meaning the person has to understand the importance of the act and not to be fooled as a result of misunderstanding the consequences of his act. Juridical act is a voluntary act as long as the law relates will with capability to act so lack of will would bring invalidity of act. In this case lawmaker reasons that the act should be made from the person who takes care of the incapable person. Acts made without the consent of the person who takes care are declared invalid from the court based on the demand of the protector ship institution. According to article 8 of Civil Code minors until 14 years are incapable of acting. They can make juridical acts adjusted to their age easily fulfilled and acts bringing profit without charge. Conclusively minors can't be part of agreements or official representatives of third persons.

\section{Juridical acts made by incapable of acting people as a result of mental diseases or incomplete growth}

In this case the act is absolutely invalid as long as the person who cares has not given his consent including here people who suffer mental diseases turning them incapable of reasoning and thinking.

\section{2 Juridical acts relatively invalid}


Juridical acts declared invalid are specified in article 94 of Civil Code. These acts are declared invalid from the court because of the different shortages and faults. Compared to absolute invalidity this one brings consequences until the moment one of the parts asks the court cancellation of the act. If time of prescription is fulfilled the act is considered valid so would bring consequences like all valid acts. The real act is cancellable but the cancellation is adjustable when time of prescription is fulfilled and parts don't ask cancellation of the act. In this case it is presumed that parts have expressed the will to change or cancel juridical consequences based on this cancellable act so in a way they consider this relatively invalid act.

if the state of stand by ends before time of prescription is fulfilled act is considered null and can't bring juridical consequences in the future.

\section{Acts made from people who lack of the consciousness of the importance of their acts}

People fully capable of acting can be in a state of not understating the importance of their acts so the express of their will cannot bring juridical consequences as long as cannot be identified with the real will of the part. People who were unconscious of the importance of their act aren't mean to be mentally diseased but just bot clear at the moment they make the act. As long as these people aren't declared incapable of acting from a court their state is defined from a group of psychiatrist. Validity of their act isn't conditioned from the consent of the person who cares as long as they are capable of acting.

\section{Juridical acts from incapable of acting people declared so due to mental diseases or unhealthy growth}

According to article 10 of Civil Code capability of acting can be removed or limited from the court when a person is mentally diseased or lacks of healthy mental growth so they aren't able to take care of themselves. These people cannot make juridical acts or be object of rights and obligations derived from juridical relations. Civil Code equals all kinds of these juridical acts not dividing them to acts from persons prived to act or limited to act. When people are limited to act from a court sentence it is not necessary to prove unconsciousness of the time of act. In this cases just the court sentence is needed to cancel the act. These acts are also invalid even when the person was mentally healthy or understood the importance of his act because life is unpredictable and we can't exclude the fact that a mentally diseased person can act normally in a moment towards the attorneys office and make acts opposed to his interests. If act made from limited to act people is made without the consent of parents or people who care this act is relatively invalid so will be canceled from the court.

When the act is made from people prived to do so this act will be considered absolutely invalid. Cancellation and consequences will come based on the state of capability to act. The decision to prive or limit a person to act is forwarded written to all courts so all the interested people to be aware of the fact. A summary of the decision is forwarded to the National Association of Attorney' Office.

\section{Acts done from minors over 14 without the consent of parents or caretaker}

Minors from 14 to 18 are limited to act. According to article 7 of Civil Code "the minor over 14 years old can make juridical acts only with the consent of his official representative who can be his parents or a caretaker ". Nevertheless acts related to the profit from their work and their administration are considered valid. Despite above exceptions minors from 14 to 18 cannot be object of civil-juridical rights and obligations without the help of parents or caretakers. Even when the act is made in the proper and legal way it will be considered invalid from the court when asked so from the interested part except from the case when parents or caretakers have given their consent. According to article 6 of Civil Code "Woman who has reached 16 earns the right to be fully capable of acting when she gets married and doesn't lose this right when she gets divorced before getting 18 ".

\section{Juridical acts under the influence of habits of will}

Will is an essential component of juridical act. Discordance of expressed will with internal will would bring habit of will. Habits of will that make acts cancelable are deception, mistake and threaten. While fictivity and simulation bring nullity of acts habits of will bring cancellation of acts. A juridical act is considered deceive when the part is intentionally pushed to 
make a mistake from the other part by rendering the conditions in an unreal way or hides the conditions that would prevent the part from acting. Juridical acts done in conditions of miscount. This acts are made when one part has a mistaken image of the circumstances that have pushed him doing this act. Miscount has to do with lack or unclear understanding of the components of juridical act. For example one person has that that according to a sale-contract has earned ownership of a property while actually he has earned a temporary usage of the property according to a rent-contract.

Juridical acts done by threatening. Threatening is an influence in persons psychological state making him to do a juridical act based on the fear of a bad cause on property or non-property interests. Not every kind of threatening brings invalidity of juridical act as a result of discordance of expressed will with internal will. Threatening should be illegal, and in discordance with general terms of right. Threatening has to be important, causing bad consequences in persons interests or his relatives. Also it has to be serious giving the idea that risks bad causes to the person or his relatives. Effectuation of threatening has to be possible and believable showing to the other part that has all the chances to do it.

According to article 96 of Civil Code: "Threatening causes invalidity of juridical act when intimidates the person so it would bring bad causes to his relatives".

Juridical acts in conditions of big need. Conditions of big need mean that a person takes responsibilities when he is in danger. In order to consider these acts invalid below conditions have to be fulfilled:

-Conditions of juridical act have to be more important than profit of them.

-One of the parts has to be in conditions of big need. Both components are needed to consider the act invalid.

According to article 99 of Civil Code juridical act is made in conditions of big need when obligations are insignificant compared with profits of the other part. Usually these acts are found when one part is economically stronger and uses this advantage making the act in conditions of unequal business.

\section{Conclusions}

Invalidity of juridical acts is clearly categorized in Albanian Civil Code predicting also juridical causes that bring these acts in involved parts. Invalid juridical acts are classified in absolute ones that are considered nul and relative ones that bring causes until their cancellation from the court.

Absolutely invalid acts never get valid with a later act of involved parts while relative invalid acts are valid when time of prescription id fulfilled because parts have expressed their will to crate or change a juridical relation giving it a juridical attribute.

\section{BIBLIOGRAPHY}

\section{Literature}

Elezi, I. (1999) "Albanian Juridical Thinking". Tirane: Albin.

Fromont,M. (2009) "Foreign systems of rights". Tirane: Papirus.

Galgano, F. (1999) "Private Rights” botimi i pare. Tirane: Luarasi.

Gjata, R. (1992) "Civil Rights" lecture. Tirane.

Lamani, A. (1962) "Civil procedure of Albanian National Republic". Tirane.

Latifi, J. (2000) "Civil Right" General Part. Tirane: Ilar.

Latifi, J. (2002) "Inheritance". Tirane: llar.

Luarasi, A. (2001) “Juridical acts" Part one. Riedition. Tirane: Luarasi.

Luarasi, A. (1999) "Juridical acts" Part two. Tirane: Luarasi. 
Mandro, A. (1998) "Roman Right". Tirane.

Nathanaili, A. (1974) "Civil Right of Albanian National Republic" General Part Edition I. Tirane.

Nathanaili, A. (1974) "Civil Right of Albanian National Republic" Special Part, Edition II. Tirane.

Nathanaili, A. (1974) “Ownership Right”. Tirane.

Nathanaili, A - Papupi, N. (1961) "Cases of ownership and inheritage". Tirane.

Nuni, A. (2009) "Civil Right", General Part. Tirane.

Nuni, A. (2001) "Juridical Acts". Tirane: Julvin.

Omari, L. (1999) "priciples and Institutions of public rights". Tirane: Elena Gjika.

Semini, M. (1998) "Contract and Obligatiob Right", general part. Tirane: Aferdita.

Semini, M. (1998) "Contract and Obligatiob Right", special part, Tirane: Aferdita.

Sallabanda, A. (1973) "Obligation's Right”, Edition I. Tiran

Zëegert \& H. Kotz "Knowledge of compared right", base priciples.

\section{Primary Sourses}

Albanian Republic Constitution of 1998.

Civil Code of 1929. Tirane: Toena, (1998).

Civil Code of National Republic of Albania of 1981. Tirane, (1982).

Civil Code National Republic of Albania of 1981. Tirane, (1982).

Albanian Republic Code with court practice of 1994. Tirane: Luarasi, (2003).

Civil Code Procedure of Albanian Republic with court practice, Tirane: Luarasi 2003.

Law nr. 2359 of 15. 11. 1956, "About Juridical acts and obligations".

Law nr. 33 of 21. 04. 2012, "About registration of real properties", changed

Law nr. 7829 of 01. 06. 1994 "About attorneys", changed.

Decret nr. 1892 of 05. 07. 1954, "About Inheritage".

Sentence number 932 of 22. 06. 2000,of " United Tribunals of Supreme Court". 